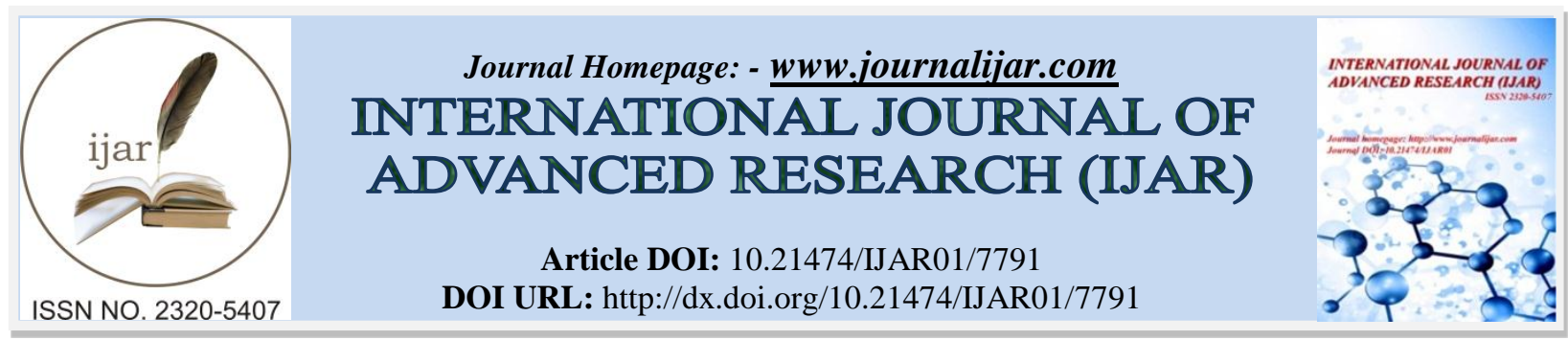

RESEARCH ARTICLE

\title{
QUALITY OF DRINKING WATER FROM HAND DUG WELLS AND BOREHOLES IN RURAL COMMUNITIES IN DEPARTMENT OF TIASSALÉ, CÔTE D'IVOIRE.
}

Adidjatou Ouattara ${ }^{1}$, Alassane Meite ${ }^{1}$, Theodor Dally ${ }^{2}$, Howélé Ouattara ${ }^{3}$ and Séraphin Kati-Coulibaly ${ }^{1}$

1. Laboratory of Nutrition and Pharmacology, UFR Biosciences, Félix Houphouët-Boigny University of Cocody, (Côte d'Ivoire).

2. UFR Environnement, Jean Lorougnon Guédé University of Daloa, (Côte d'Ivoire).

3. UFR Biological Sciences, Péléforo Gon Coulibaly University of Korhogo, (Côte d'Ivoire)

\section{Manuscript Info}

\section{Manuscript History}

Received: 2 August 2018

Final Accepted: 4 September 2018

Published: October 2018

Keywords:

Groundwater, boreholes, hand dug wells, quality.

\begin{abstract}
Groundwater from boreholes and hand dug wells is a major source of drinking water in most rural areas of Côte d'Ivoire. A study was conducted to evaluate drinking water quality and the level of risk of contamination from wells in rural areas in department of Tiassalé. The level of risk of contamination for each well was determined from a checklist with ten questions on risk factors for contamination, recommended by WHO. The results of surveyed wells showed a risk of contamination ranging from a low rick to very high risk. Groundwater quality physico-chemical indicators used in this study were $\mathrm{pH}$, temperature, electrical conductivity, turbidity, nitrates and nitrites. The microbiological indicators were faecal coliforms, Escherichia Coli, faecal enterococci and Pseudomonas aeruginosa. $\mathrm{pH}$ was found to be 4.4-7, temperature $22.7-32^{\circ} \mathrm{C}$,turbidity $0.01-30.6 \mathrm{NTU}$, nitrate 2.33 $78.8 \mathrm{mg} / \mathrm{L}$ and nitrite $0.010-0.28 \mathrm{mg} / \mathrm{L}$. Hand dug wells waters had values of turbidities, nitrites and nitrates statistically higher than boreholes $(P<0.05)$. Results of this study shows that water from hand dug wells are contains high levels of pathogenic and indicators microorganisms than boreholes. The consumption waters from hand dug wells exposes consumers to serious health risks, thus requiring appropriate treatment before consumption.
\end{abstract}

Copy Right, IJAR, 2018,. All rights reserved.

\section{Introduction:-}

Water is an important component of human body and is the need of life (Muhammad et al., 2012). Presence of deterious chemicals and pathogenic microbes can cause a serious health problem, leading to infections and death (Lima et al., 2005). The drinking water contaminated with any pathogenic bacteria is unsafe for human consumption and household use (Muhammad et al., 2012). Access to safe drinking water is not only the prime need for survival and health but is also basic human rights (WHO, 2000). Safety of drinking water remains an important public health concern particularly in emergency situations (Ferretti et al., 2010). Pathogens that cause diarrheal diseases are being linked with contaminated water consumption, such pathogens are the main cause of gastrointestinal infections. The childhood mortality rate due to diarrheal diseases is 2.5 million each year (Muhammad et al., 2012). Each year approximately five million children die due to the use of unsafe water (Shar et al., 2010). Approximately 1.8 million 
kids died in developing countries caused by biological agents or microorganisms originating from food and water in year 1998 (Akbar and Anal, 2011). Vulnerable and Unsafe drinking water supplies are contributing in high rate of human morbidity and mortality worldwide.

Unprotected or protected communal water sources are the key means of potable water in many developing countries. It has been estimated that $1 / 3$ of the total world population use ground water for drinking purpose (Nickson et al., 2005). Obtaining safe water from a communal source remains a prime concern of the people in developing countries (Joyce et al., 1996). Vulnerable sewage and sanitation lines and direct discharge of waste to natural reservoirs and water bodies are the major cause of contamination (Huttly, 1990).

A group of bacteria called indicators are the primary indicator of water pollution. The presence of these microbes is associated with the presence of disease causing microorganisms (Muhammad et al., 2013; Shar et al., 2010). Bacteriological examination of water samples are usually undertaken to estimate the water quality. Most of the waterborne disease is related to faecal pollution of water sources.

This study was undertaken to assess the microbiological and chemical quality of water from hand dug wells and boreholes in department of Tiassalé. Additional objectives of this study were to identify structural deficiencies and users incorrect behaviours responsible for microbiological well water contamination.

\section{Materials and Methods:- \\ Study area}

The study were conducted in the department of Tiassale located in the South of Côte d'Ivoire. It belongs AGNEBYTIASSA region, between $5^{\circ} 32^{\prime}$ to $6^{\circ} 24^{\prime}$ North latitude and $4^{\circ} 29^{\prime}$ to $5^{\circ} 14^{\prime}$ West longitude. This department has an area of $3370 \mathrm{~km}^{2}$ and a population estimated to 81180 women and $98702 \mathrm{man}$. It includes four prefectures that are Tiassalé, N'douci, Gbolouville and Morokro. The number of households is 38996 with an average size of 5 persons per household. More than half of households live in rural areas (68.1\%) compared to $31.1 \%$ in urban areas (INS, 2014). In the department, the majority of populations, especially in rural areas, use wells (hand dug wells and boreholes) water for domestic water supplies. The Households are characterized by a low socioeconomic status and are located on sites lacking hygiene and assainissment infrastructure.

\section{Selection of wells}

A census of wells has been made. For multiple reasons such as insufficiency of funds, we sampled a subset of the wells. The choice is mainly justified by their importance for the supply of drinking water of the households. The selection was based on the nearness to a potential source of water contamination, nature of wells and type of wells (private or public). In addition, geographical location was considered to attain good spatial representation. Hand-dug wells were coded from the letter $\mathrm{P}$ followed by the first three letters and the sampling order of the locality. Boreholes were coded from the letter F followed by the first three letters and the sampling order of the locality. For a locality with one (1) borehole, the code does not carry a sampling order. A hand-held GPS (Garmin) was used for the location of these sampling points. The characteristics of the sampled hand dug wells and the boreholes were documented in Table 1 and 2.

\section{Inspection of wells and assessment of Risk of Contamination}

The sanitary inspection principle is based on the assumption that every fault (negative point), that may reduce the water quality of the supply system by observation. Inspection forms used included ten risk factors on potential sources of pollution (Mushi et al., 2012). WHO (1997) established a format for inspection forms consisting of a set of questions which have 'yes' or 'no' answers. The questions are structured such that 'yes' answers indicate that there is a reasonable risk of contamination and 'no' answers indicate that the particular risk appears to be negligible (Mushi et al., 2012). Each 'yes' answer scores one point and each 'no' answer scores zero points. A final risk score was computed for each water point by calculating the number of positive factors as a percentage of the total number of factors being assessed. A higher risk of contamination score represents a greater risk that drinking water is contaminated by faecal pollution from the area immediately surrounding the well (Godfrey et al., 2006; Vaccari et al., 2009; Mushi et al., 2012). Four classes of contamination risk score were suggested, low (0-20\%), intermediate (30-50\%), high (60-70\%) and very high (80-100\%) (Mushi et al., 2012, WHO, 1997). 
Table 1:-Geographic coordinates of sampled Hand-dug wells

\begin{tabular}{|c|c|c|c|}
\hline \multirow[t]{2}{*}{ Localities } & \multirow[t]{2}{*}{ Code Hand-dug wells } & \multicolumn{2}{|c|}{ Geographic coordinates } \\
\hline & & Latitude & longitude \\
\hline \multirow[t]{3}{*}{ Bandjoukro } & PBan1 & $05^{\circ} 47.940^{\prime}$ & $004^{\circ} 35.135^{\prime}$ \\
\hline & PBan2 & $05^{\circ} 47.876^{\prime}$ & $004^{\circ} 35.956^{\prime}$ \\
\hline & PBan3 & $05^{\circ} 48.305^{\prime}$ & $004^{\circ} 35.953^{\prime}$ \\
\hline \multirow[t]{2}{*}{ Binao } & PBin1 & $05^{\circ} 49.065^{\prime}$ & $004^{\circ} 35.486^{\prime}$ \\
\hline & PBin2 & $05^{\circ} 49.089^{\prime}$ & $004^{\circ} 35.596^{\prime}$ \\
\hline \multirow{7}{*}{ N'drikro } & PNdr1 & $05^{\circ} 49.789^{\prime}$ & $004^{\circ} 36.590^{\prime}$ \\
\hline & PNdr2 & $05^{\circ} 49.816^{\prime}$ & $004^{\circ} 36.572^{\prime}$ \\
\hline & PNdr3 & $05^{\circ} 49.778^{\prime}$ & $004^{\circ} 36.542^{\prime}$ \\
\hline & PNdr4 & $05^{\circ} 49.762^{\prime}$ & $004^{\circ} 36.570^{\prime}$ \\
\hline & PNdr5 & $05^{\circ} 50.037^{\prime}$ & $004^{\circ} 36.708^{\prime}$ \\
\hline & PNdr6 & $05^{\circ} 49.907^{\prime}$ & $004^{\circ} 36.715^{\prime}$ \\
\hline & PNdr7 & $05^{\circ} 49.859^{\prime}$ & $004^{\circ} 36.674^{\prime}$ \\
\hline \multirow{7}{*}{ Boussoukro } & PBou1 & $05^{\circ} 52.730^{\prime}$ & $004^{\circ} 41.695^{\prime}$ \\
\hline & PBou2 & $05^{\circ} 52.724^{\prime}$ & $004^{\circ} 41.705^{\prime}$ \\
\hline & PBou3 & $05^{\circ} 52.717^{\prime}$ & $004^{\circ} 41.699^{\prime}$ \\
\hline & PBou4 & $05^{\circ} 52.715^{\prime}$ & $004^{\circ} 41.709^{\prime}$ \\
\hline & PBou5 & $05^{\circ} 52.717^{\prime}$ & $004^{\circ} 41.707^{\prime}$ \\
\hline & PBou6 & $05^{\circ} 52.728^{\prime}$ & $004^{\circ} 41.702^{\prime}$ \\
\hline & PBou7 & $05^{\circ} 52.725^{\prime}$ & $004^{\circ} 41.705^{\prime}$ \\
\hline \multirow{4}{*}{ Offa } & POff1 & $05^{\circ} 52.848^{\prime}$ & $004^{\circ} 41.503^{\prime}$ \\
\hline & POff2 & $05^{\circ} 52.845^{\prime}$ & $004^{\circ} 41.508^{\prime}$ \\
\hline & POff3 & $05^{\circ} 52.843^{\prime}$ & $004^{\circ} 41.507^{\prime}$ \\
\hline & POff4 & $05^{\circ} 53.175^{\prime}$ & $004^{\circ} 41.754^{\prime}$ \\
\hline \multirow{8}{*}{ Niamazra } & PNial & $05^{\circ} 53.373^{\prime}$ & $004^{\circ} 37.939^{\prime}$ \\
\hline & PNia2 & $05^{\circ} 53.331^{\prime}$ & $004^{\circ} 38.000^{\prime}$ \\
\hline & PNia3 & $05^{\circ} 53.264^{\prime}$ & $004^{\circ} 37.915^{\prime}$ \\
\hline & PNia4 & $05^{\circ} 53.241^{\prime}$ & $004^{\circ} 37.981^{\prime}$ \\
\hline & PNia5 & $05^{\circ} 53.221^{\prime}$ & $004^{\circ} 38.083^{\prime}$ \\
\hline & PNia6 & $05^{\circ} 53.014^{\prime}$ & $004^{\circ} 38.091^{\prime}$ \\
\hline & PNia7 & $05^{\circ} 53.122^{\prime}$ & $004^{\circ} 38.084^{\prime}$ \\
\hline & PNia8 & $05^{\circ} 53.188^{\prime}$ & $004^{\circ} 38.114^{\prime}$ \\
\hline \multirow[t]{13}{*}{ Batera } & PBat1 & $05^{\circ} 50.199^{\prime}$ & $004^{\circ} 43.987^{\prime}$ \\
\hline & PBat2 & $05^{\circ} 50.134^{\prime}$ & $004^{\circ} 43.134^{\prime}$ \\
\hline & PBat3 & $05^{\circ} 50.162^{\prime}$ & $004^{\circ} 33.871^{\prime}$ \\
\hline & PBat4 & $05^{\circ} 50.179^{\prime}$ & $004^{\circ} 43.812^{\prime}$ \\
\hline & PBat5 & $05^{\circ} 50.163^{\prime}$ & $004^{\circ} 43.848^{\prime}$ \\
\hline & PBat6 & $05^{\circ} 50.140^{\prime}$ & $004^{\circ} 43.804^{\prime}$ \\
\hline & PBat7 & $05^{\circ} 50.219^{\prime}$ & $004^{\circ} 43.707^{\prime}$ \\
\hline & PBat8 & $05^{\circ} 50.214^{\prime}$ & $004^{\circ} 43.683^{\prime}$ \\
\hline & PBat9 & $05^{\circ} 50.232^{\prime}$ & $004^{\circ} 43.643^{\prime}$ \\
\hline & PBat10 & $05^{\circ} 50.308^{\prime}$ & $004^{\circ} 43.791^{\prime}$ \\
\hline & PBat11 & $05^{\circ} 50.142^{\prime}$ & $004^{\circ} 43.998^{\prime}$ \\
\hline & PBat12 & $05^{\circ} 50.092^{\prime}$ & $004^{\circ} 43.923^{\prime}$ \\
\hline & PBat13 & $05^{\circ} 50.125^{\prime}$ & $004^{\circ} 43.802^{\prime}$ \\
\hline
\end{tabular}


Table 2:-Geographic coordinates of sampled boreholes.

\begin{tabular}{|c|c|c|c|}
\hline \multirow{2}{*}{ Localities } & Code Boreholes & \multicolumn{2}{|c|}{ Geographic coordinates } \\
\cline { 2 - 4 } & & Latitude & $004^{\circ} 35.159^{\prime}$ \\
\hline Binao & FBin & $05^{\circ} 48.839^{\prime}$ & $004^{\circ} 36.614^{\prime}$ \\
\hline N'drikro & FNdr & $05^{\circ} 49.885^{\prime}$ & $004^{\circ} 41.743^{\prime}$ \\
\hline Boussoukro & FBou & $05^{\circ} 52.758^{\prime}$ & $004^{\circ} 38.084^{\prime}$ \\
\hline Niamazra & FNia1 & $05^{\circ} 53.203^{\prime}$ & $004^{\circ} 38.089^{\prime}$ \\
\cline { 2 - 4 } & FNia2 & $05^{\circ} 53.328^{\prime}$ & $004^{\circ} 43.948^{\prime}$ \\
\hline Batera & FBat & $05^{\circ} 50.196^{\prime}$ & \\
\hline
\end{tabular}

\section{Sample collection}

The collection of water samples from each well was made according to three campaigns in 2016 and method of water sample collection at each source was according to the WHO Guidelines for drinking water quality assessment (WHO, 2004). The drinking water samples were collected aseptically from the water at hand dug wells and boreholes. The ground water sampling in wells equipped with a pump was operated after two minutes of water flowing. In the remaining wells provided with ropes and buckets, samples were collected using the in situ bucket and rope systems within each well (Vaccari et al., 2010). The sample in sterile glass bottle was used for bacteriological analysis and the other, in the polyethylene bottle, for physico-chemical analysis (APHA, 2012). At each sampling point, two water samples were collected, one in a sterile glass bottle and the other in a polyethylene bottle. After collection, the bottles were labeled with complete details, including the source of the water, the sample site, the GPS coordinates, the date and time of collection. All samples were stored and transported in an insulated box filled with ice packs and transported immediately to the laboratory. All collected samples were kept at $4{ }^{\circ} \mathrm{C}$ and analyzed within $2 \mathrm{~h}$ of collection (Vaccari et al., 2010).

\section{Physico-chemical and Microbiological analysis}

Table 3 lists the methods, expressions and reference values used for each parameters physico-chemical and microbiological.

\section{Physico-chemical analysis}

Water of each sample was also tested for its $\mathrm{pH}$, turbidity, temperature, electrical conductivity, nitrite and nitrate on the collection spot. $\mathrm{pH}$, turbidity and temperature were chosen in accordance with their general importance in bacterial metabolism. The electrical conductivity is the expression of the load of the dissolved salts, it allows to evaluate the global mineralization by the quantity of ions in solution. Nitrite and nitrate levels may reflect groundwater pollution by anthropogenic activities and pose a risk to the health of populations. The temperature and the $\mathrm{pH}$ of the water samples were measured immediately after collection. The $\mathrm{pH}$ meter was used for the $\mathrm{pH}$ and temperature measurement. Turbidity were determined with turbidity meter. Electrical conductivity was measured with Handheld Conductivity Meter. Nitrate and nitrite were determined by a colorimetric method using a UVVisible spectrophotometer type. Calibration and standardization of apparatus were performed according to the manufacturer's instructions before analyzes (Rodier et al., 2009).

Table 3:-Characteristics of each parameters and their threshold values

\begin{tabular}{|c|c|c|c|}
\hline Parameters & Methods & Expression & Reference values \\
\hline $\mathrm{pH}$ & ISO $10523: 2008$ & - & $6,5<\mathrm{pH}<8,5$ \\
\hline Température & ISO $10523: 2008$ & ${ }^{\circ} \mathrm{C}$ & $25^{\circ} \mathrm{C}$ \\
\hline Electrical conductivity & ISO 7888-1985 & $\mu \mathrm{S} / \mathrm{cm}$ & 500 \\
\hline Turbidity & ISO $7027: 1999$ & $\mathrm{NTU}$ & $5 \mathrm{NTU}$ \\
\hline Nitrate & ISO 7890-3:1988 & $\mathrm{mg} / \mathrm{L}$ & $0,1 \mathrm{mg} / \mathrm{L}$ \\
\hline Nitrite & ISO 6777 : 1984 & $\mathrm{mg} / \mathrm{L}$ & $<1$ \\
\hline Feacal coliforms & ISO 9308-1 & $\mathrm{CFU} / 100 \mathrm{~mL}$ & $<1$ \\
\hline Escherichia coli & ISO 9308-1 & $\mathrm{CFU} / 100 \mathrm{~mL}$ & $<1$ \\
\hline Faecal enterococci & ISO 7899-2 & $\mathrm{CFU} / 100 \mathrm{~mL}$ & $<1$ \\
\hline
\end{tabular}




\section{Bacteriological analysis}

Microbiological analysis included detection feacal coliforms, Escherichia coli, faecal enterococci and Pseudomonas aeruginosa. These are bacterial indicators in which used in water quality and health risk assessments. Escherichia coli and faecal enterococci are exclusively faecal in origin, it is bacterial indicator in which used in water quality and health risk assessments and used by the United Nations, the World Health Organization, and a variety of other organizations worldwide. It is normally prevalent in the intestines and feces of warmblooded mammals including livestock and humans. Escherichia coli are regarded as the most reliable indicator of faecal contamination and relates to the risk of contracting a water-borne disease. Pseudomonas aeruginosa is an opportunistic pathogen. It is responsible for diarrhea, genitourinary and eye infections in immunodeficient people (Davraz and Varol, 2011). Membrane filtration was used to enumerate microbial according to the standard methods (APHA, 2012). For each wells, raw/diluted water sample was filtered through a sterile $47 \mathrm{~mm}, 0.45 \mu \mathrm{m}$-pore-diameter, gridded membrane filter, under partial vacuum. The bacteria were detected by the conventional culture method (Standard Methods for the Examination of Water and Wastewater, 1995). Colonies were counted after inoculation of agar media plates according to the method used.

\section{Statistical analysis}

Changes in bacterial densities and physicochemical parameters of water at the different sampling wells were recorded using software STATISTICA version 7. Parameters of water quality were compared with guideline values for drinking water given by the World Health Organization (WHO, 2004). A non-parametric Mann Whitney test was performed to determine if there was significant variation in the water quality with respect to type of groundwater sources (wells type) in localities with both types of wells, a probability value of $\mathrm{P}<0,05$ was considered statistically significant. To classify the sampling sites according to the properties of their water samples, a hierarchical cluster analysis (HCA) of water points was conducted. These two analyses were applied using the software XLSTAT version (2015). Software EXCEL (2013) and STATISTICA version 7 were used for the different figures.

\section{Results:-}

\section{Risk of Contamination of Surveyed Wells}

Table 4 resume the percentage of answers for each question contained in the check list. The answers of questions in the Checklist indicated that near the wells surveyed, there are often latrines ( $24 \%$ of cases). Only $8 \%$ of the considered wells have their own area defined by a fence. $88 \%$ of the wells have no drainage channel. In many cases, presence of stagnant water was observed around the wells (72\%). Pavement surrounding the well is missing for 68 $\%$ of cases observed. $32 \%$ of wells surveyed have no headwall. In $64 \%$ of cases, wells were open. Wastes was observed around $42 \%$ of the wells surveyed. The lack of maintenance of the well was observed at the level of $56 \%$ the wells investigated. The withdrawal system of water of $88 \%$ of wells was exposed to contamination. Considering the total score of each well, the results obtained show that no well presented a total absence of risk of contamination. Based on the risk of contamination scoring, the surveyed wells could be placed into four categories. Only 5 out of 50 wells showed a low contamination risk score (0-20\%). An intermediate score was noted in 9 wells $(40-50 \%)$. The greater part of the wells (20 out of 50 wells) are characterized by high score (60-70\%) and very high scores (80-100 \%) for 16 wells (Fig. 1). The last three risks were characterized by the hand dug wells.

Table 4:-Summary of the responses of the checklist

\begin{tabular}{|c|c|c|c|c|}
\hline \multirow[t]{2}{*}{ Risk factors for contamination } & \multicolumn{2}{|c|}{ Yes } & \multicolumn{2}{|c|}{ No } \\
\hline & $\mathrm{n}$ & $\%$ & $\mathrm{n}$ & $\%$ \\
\hline 1-Latrine at $<10 \mathrm{~m}$ & 12 & 24 & 38 & 76 \\
\hline 2-Missing fencing around the well & 46 & 92 & 4 & 8 \\
\hline 3- Absence of drainage channel & 44 & 88 & 6 & 12 \\
\hline 4-Stagnant water within $2 \mathrm{~m}$ & 36 & 72 & 14 & 28 \\
\hline 5-Missing pavement surrounding the well & 34 & 68 & 16 & 32 \\
\hline 6- Missing headwall around the well & 16 & 32 & 34 & 68 \\
\hline 7-Absence of cover on the well & 32 & 64 & 18 & 36 \\
\hline 8- Presence of other source of pollution (wastes) within $10 \mathrm{~m}$ of well & 21 & 42 & 29 & 58 \\
\hline 9- Lack of maintenance of the well & 28 & 56 & 22 & 44 \\
\hline 10-Withdrawal system of water exposed to contamination & 44 & 88 & 6 & 12 \\
\hline
\end{tabular}

$\mathrm{n}$ : Number of wells ; \% : Proportion of wells. 


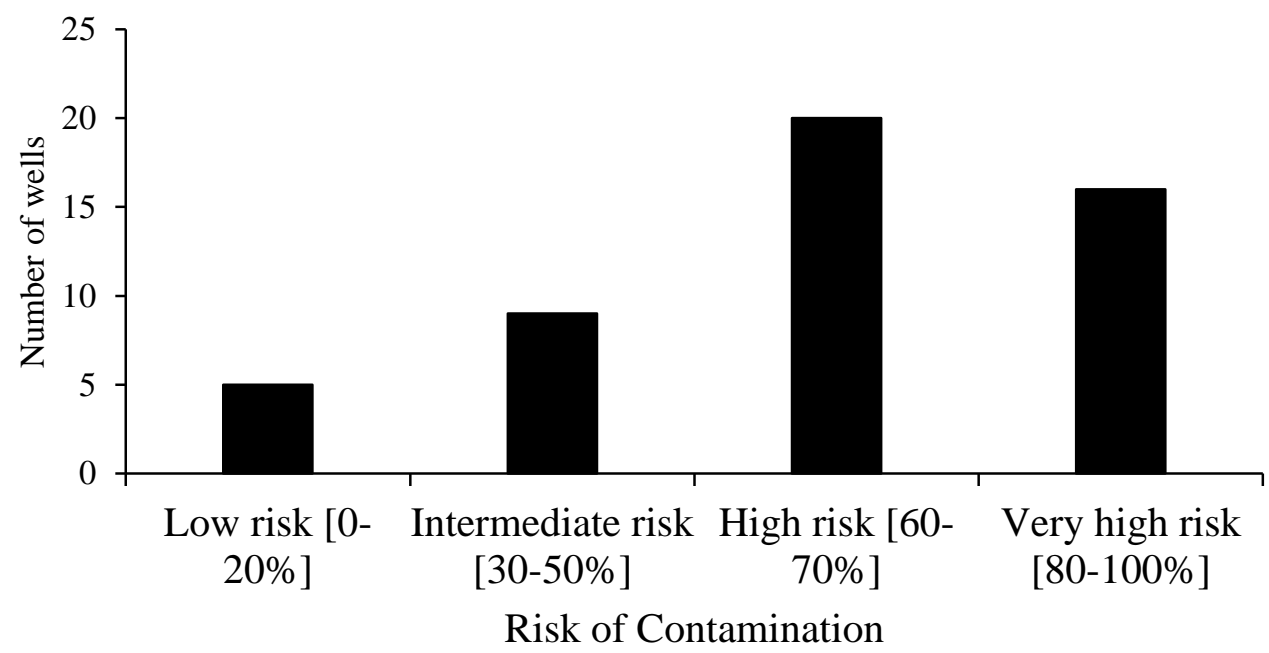

Fig. 1:-Distribution of the proportion of wells according to the level of risk of contamination

\section{Physicochemical water quality}

pH

The $\mathrm{pH}$ of water samples in hand dug wells ranged between 4.4 (PNia6 and PBat12) and 7 (POff2). pH of the water sample in boreholes ranged from 4.8 (FBin) to 6.9 (FBat). There are not different significant in pH value in waters from hand dug wells and boreholes ( $\mathrm{P}>0.05)$ (Fig. 2).

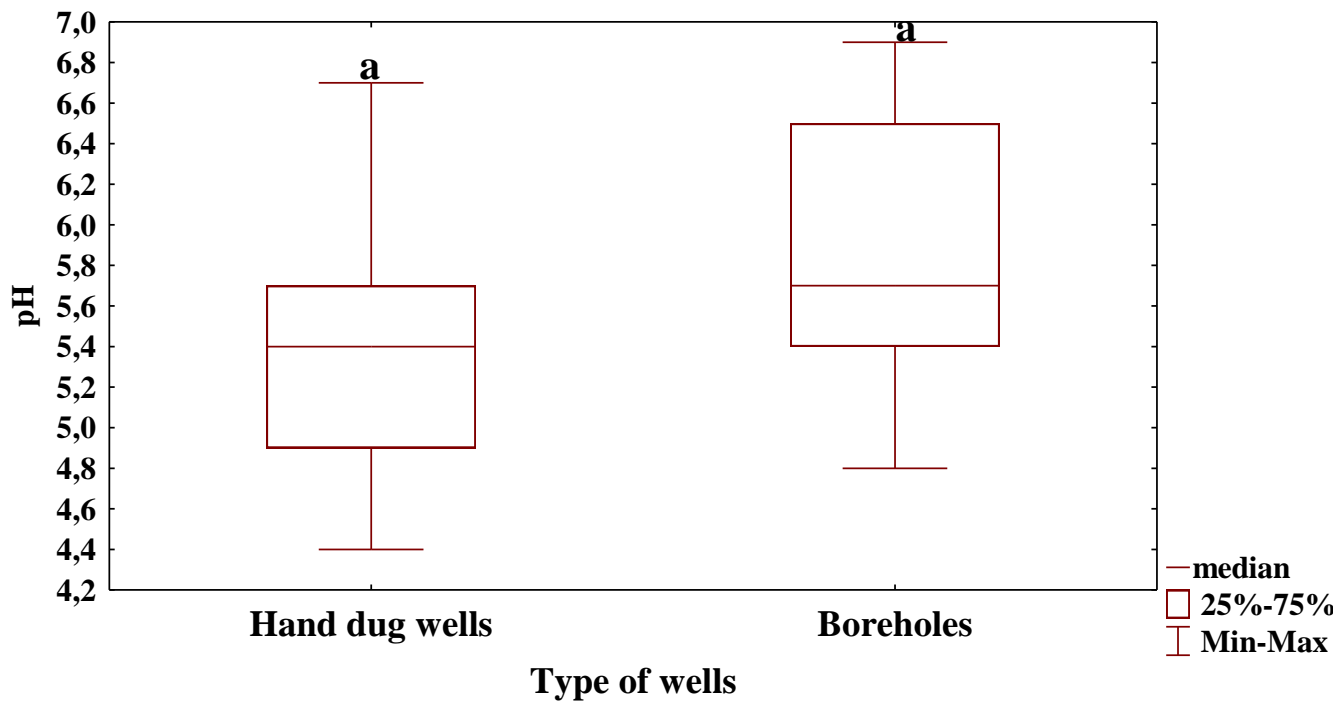

Fig. 2:-Box plots with $\mathrm{pH}$ values of waters of hand dug wells and boreholes.

The alphabetical letter (a) on the boxes indicates that there is no significant difference between the $\mathrm{pH}$ values of boreholes and hand dug wells (Mann withney test, $\mathrm{P}>0.05$ ). 


\section{Electrical conductivity}

Electrical conductivity is a tool to assess the purity of water. The electrical conductivity values oscillated between $33.7 \mu \mathrm{S} / \mathrm{cm}$ at hand dug well PBin2 and $680 \mu \mathrm{S} / \mathrm{cm}$ at hand dug well PNia4. The values of electrical conductivity of borehole waters presented variation according to boreholes. These values varied from $115 \mu \mathrm{S} / \mathrm{cm}$ at borehole FNdr to $939 \mu \mathrm{S} / \mathrm{cm}$ at borehole FBou. Fig. 3 indicate here were significant differences in electrical conductivity between hand dug wells and Boreholes $(\mathrm{P}<0.05)$.

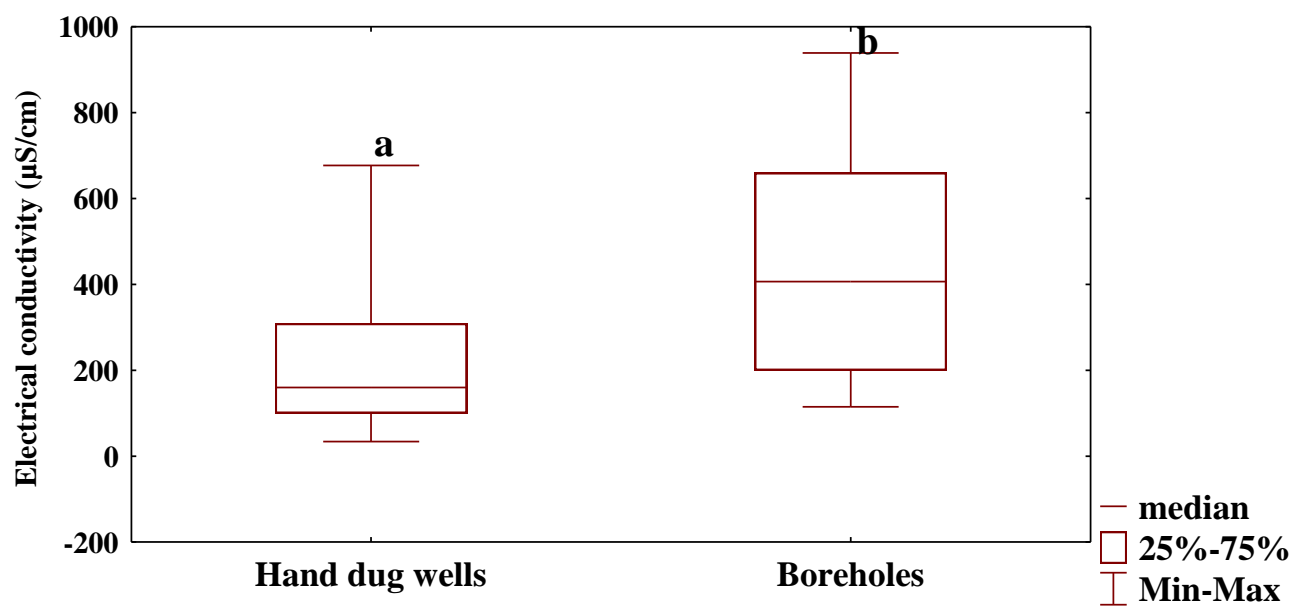

\section{Type of wells}

Fig. 3:-Box plots with Electrical conductivity values of waters of hand dug wells and boreholes.

The different alphabetic letters ( $a$ and $b$ ) on the boxes indicate a significant difference between the turbidities of waters of hand dug wells and boreholes (Mann withney, $\mathrm{P}<0.05$ ).

\section{Temperature}

The temperature of hand dug wells waters samples spans from $22.7^{\circ} \mathrm{C}$ (PBou2) to $32{ }^{\circ} \mathrm{C}$ (POff2). In waters sample from boreholes, the temperature ranged from $26.2^{\circ} \mathrm{C}$ (FBin) $-31.9^{\circ} \mathrm{C}$ (FBou). There are not different significant in $\mathrm{pH}$ value in water from hand dug well and boreholes $(\mathrm{P}>0.05)$ (Fig. 4).

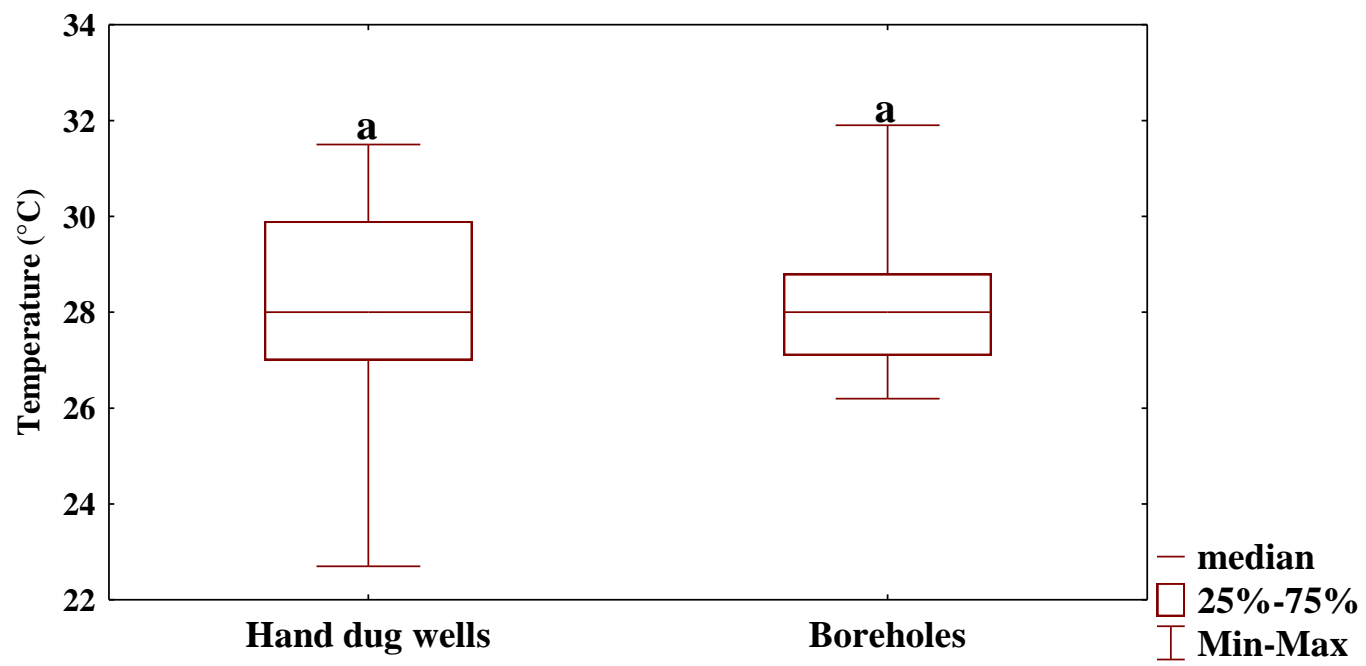

Type of wells

Fig. 4:-Box plots with temperature values of waters of hand dug wells and boreholes.

The alphabetical letter (a) on the boxes indicates that there is no significant difference between the temperature values of boreholes and hand dug wells (Mann withney test, $\mathrm{P}>0.05$ ). 


\section{Turbidity}

The turbidities were found to range from 3.9 NTU (PBat2) to 30.6 NTU (PBou7) for waters of hand dug wells. Levels of turbidity in water from boreholes found in this study ranged from $0.01 \mathrm{NTU}$ (FBou, FBin and FNdr) to 2.1 NTU (FBat). Hand dug wells waters had turbidities statistically higher than boreholes $(\mathrm{P}<0.05)$ (Fig. 5).

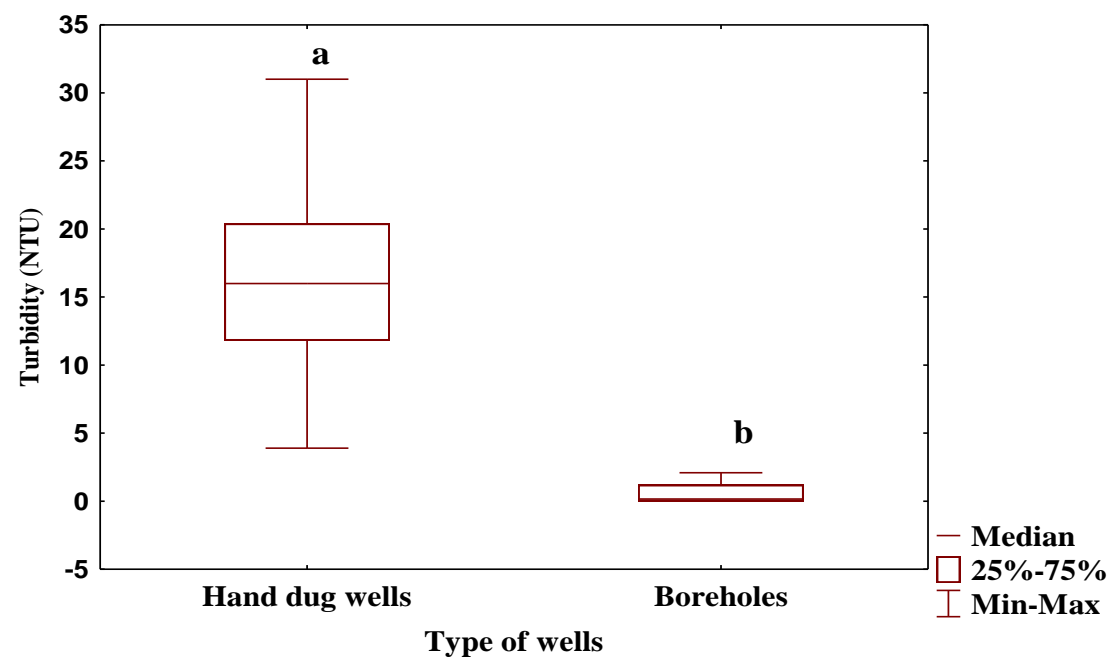

Fig. 5:-Box plots with turbidity values of waters of hand dug wells and boreholes.

The different alphabetic letters ( $a$ and $b$ ) on the boxes indicate a significant difference between the turbidities of waters of hand dug wells and boreholes (Mann withney, $\mathrm{P}<0.05$ ).

\section{Nitrates}

The level of nitrates in the waters sample from hand dug wells varied from $2.33 \mathrm{mg} / \mathrm{L}$ (PBan1) to $78.8 \mathrm{mg} / \mathrm{L}$ (PBat13). The nitrate of the boreholes was found to be in the range $4.03 \mathrm{mg} / \mathrm{L}$ (FNdr) $-28.3 \mathrm{mg} / \mathrm{L}$ (FBou). The Mann Whitney test indicated that boreholes had statistically lower nitrate levels than hand dug well waters $(\mathrm{P}<0.05)$ (Fig. $6)$.

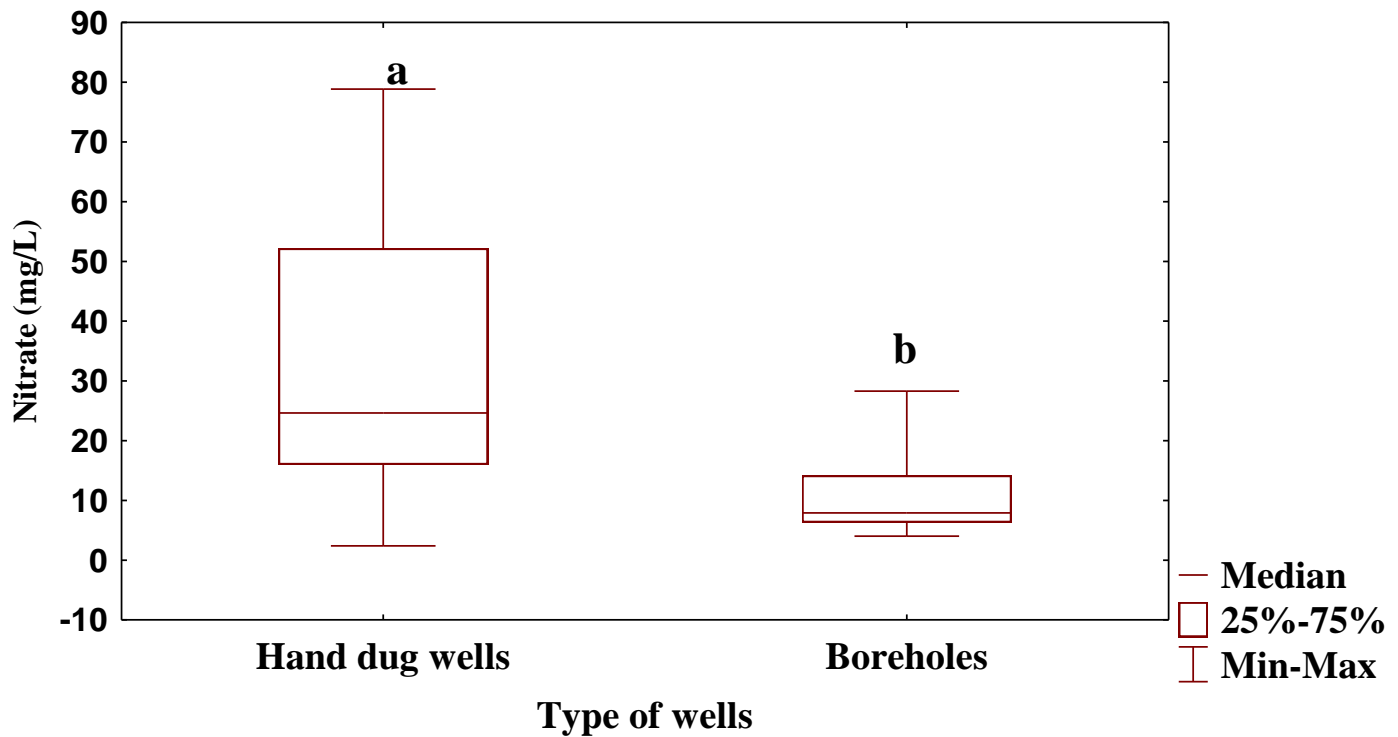

Fig. 6:-Box plots with nitrates concentrations of waters of hand dug wells and boreholes.

The different alphabetic letters ( $a$ and $b$ ) on the boxes indicate a significant difference between the nitrates of waters of hand dug wells and the boreholes (Mann Whitney Test, $\mathrm{P}<0.05$ ). 


\section{Nitrites}

Nitrite values ranged between 0.010 (POff2) and $0.28 \mathrm{mg} / \mathrm{L}$ (PNdr3) from waters in hand dug wells. They were found to be $0.011 \mathrm{mg} / \mathrm{L}$ (FBin) $-0.085 \mathrm{mg} / \mathrm{L}$ (FBou) in water sample from boreholes. Hand dug wells waters showed nitrite levels statistically higher than that of boreholes $(\mathrm{P}<0.05)$ (Fig. 7).

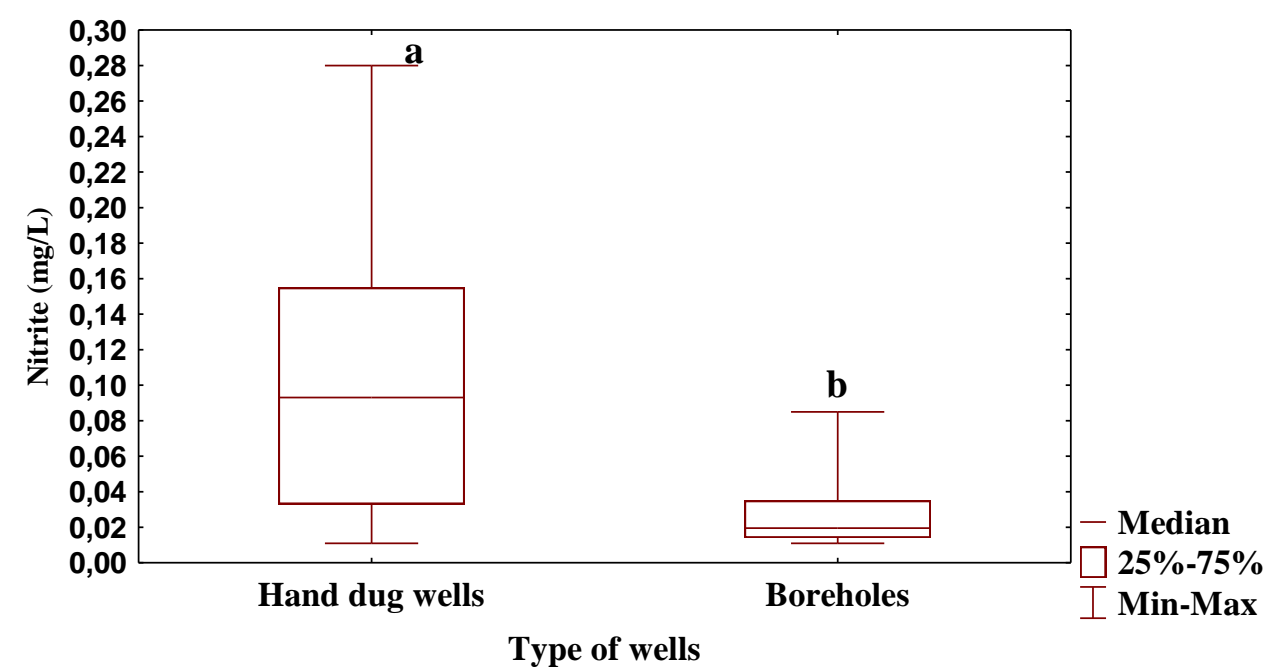

Fig. 7:-Box plots with nitrites concentrations of waters of hand dug wells and boreholes.

The different alphabetic letters ( $a$ and $b$ ) on the boxes indicate a significant difference between the nitrites of waters of hand dug wells and the boreholes (Mann Whitney Test, $\mathrm{P}<0.05$ ).

\section{Microbiological water quality}

Majority of the drinking water were found unprotected. Fig. 8 to fig. 11 illustrate the percentage of nonconformities of faecal coliforms, Escherichia coli, faecal enterococci and Pseudomonas aeruginosa in waters sample from hand dug wells and boreholes. Waters from hand dug wells showed the highest concentration of feacal coliforms (98\%), Escherichia coli (93\%), faecal enterococci (100\%) and Pseudomonas aeruginosa (89\%) relative to boreholes. It was observed that $17 \%$ of the waters from boreholes evaluated were found contaminated by feacal coliforms, Escherichia coli, faecal enterococci and Pseudomonas aeruginosa.

\section{- Uncontaminated Contaminated}

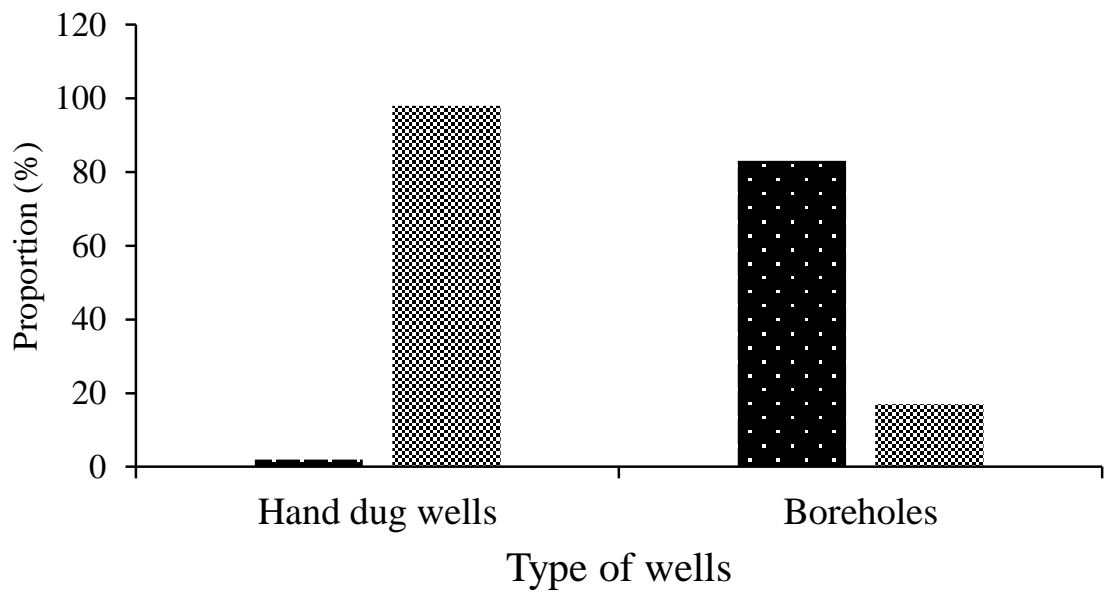

Fig. 8:-Distribution of samples according to faecal coliforms contamination and wells type 


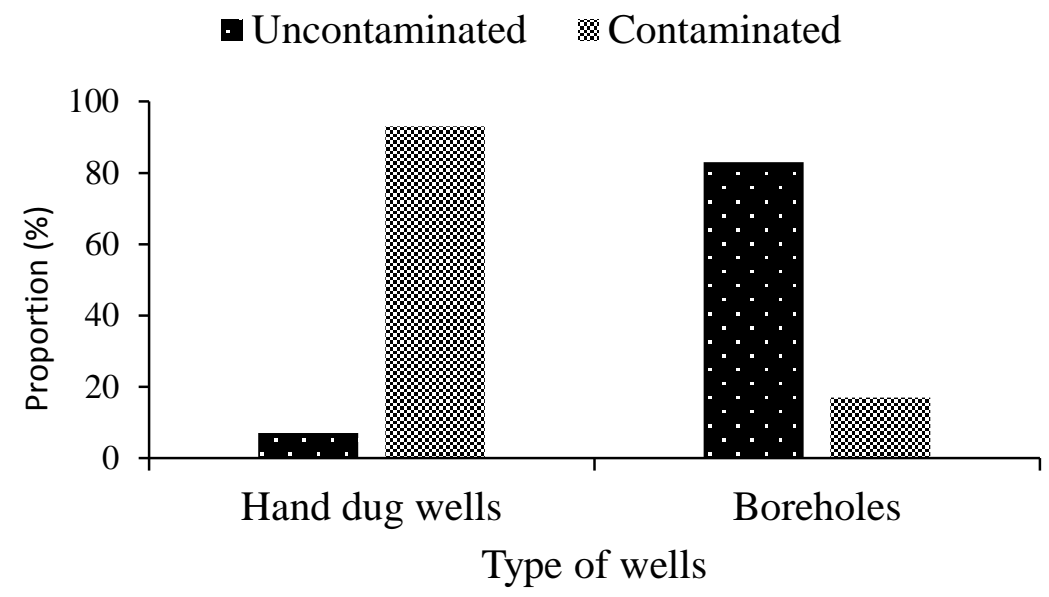

Fig. 9:-Distribution of samples according to Escherichia coli contamination and wells type

- Uncontaminated Contaminated

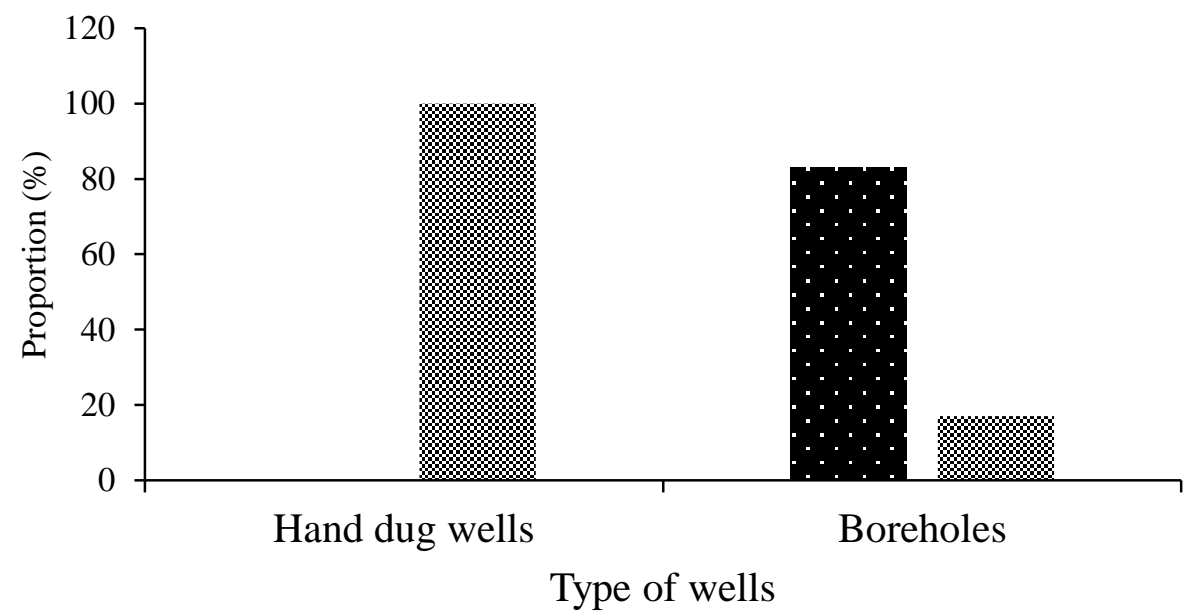

Fig. 10:-Distribution of samples according to faecal enterococci contamination and wells type 


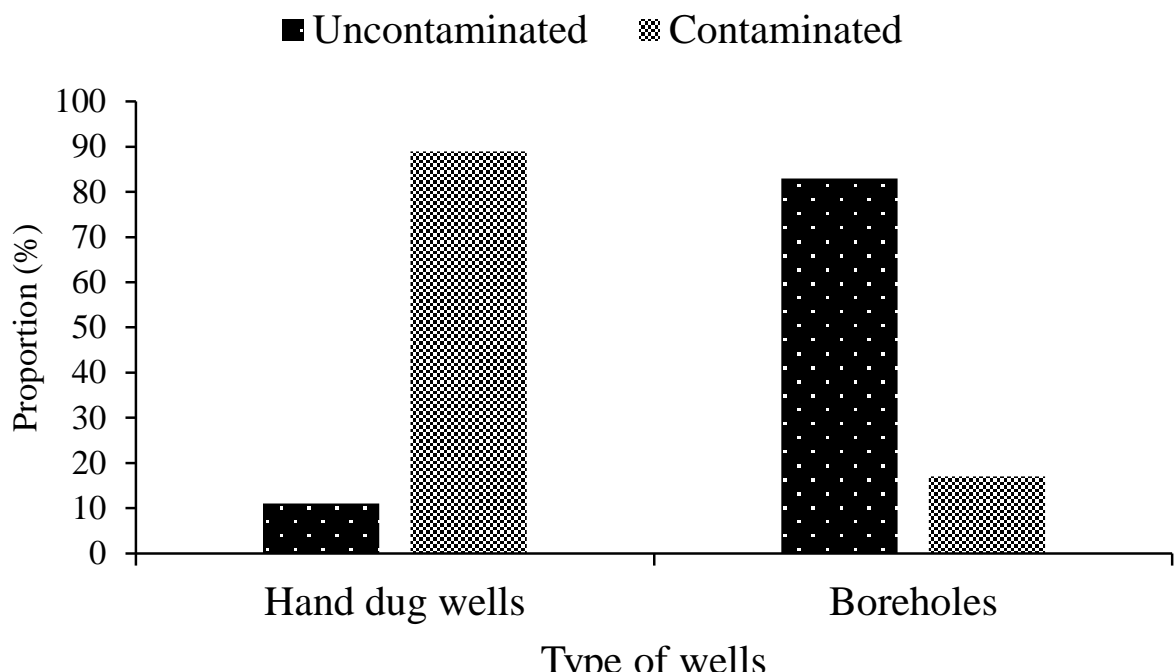

Fig. 11:-Distribution of samples according to Pseudomonas aeruginosa contamination and wells type

\section{Hierarchical cluster analysis (HCA) of water points \\ Hierarchical cluster analysis of hand dug wells}

The assessment of the quality of water samples has been made by categorizing sampled hand dug wells in similar zones. Fig. 12 presents results of classification of the sampled points (hand dug wells). Three main classes were distinguished: $\mathrm{C} 1, \mathrm{C} 2$ and $\mathrm{C} 3$.

-Class C1, hand dug wells (PBan2, PBin1, PBin2, PNdr3, PBou1, PBou2, PBou3, PBou4, PBou5, PBou6, PBou7, POff1, POff2, POff4, PNia1, PNia7, PNia8, PBat2, PBat6, PBat9, PBat10 and PBat11) were characterized by had high of bacterial abundance ;

-Class C2, hand dug wells (PNia2, PNia4, PNia5, PBat3, PBat4, PBat5, PBat12 and PBat13) presented high values of electrical conductivity and nitrates;

-Class C3, hand dug wells (PBan1, PBan3, PNdr1, PNdr2, PNdr4, PNdr5, PNdr6, PNdr7, POff3, PNia3, PNia6, PBat1, PBat7 and PBat8) presented lower bacterial values than class $\mathrm{C} 1$.

\section{Hierarchical cluster analysis of boreholes}

Fig. 13 presents results of classification of the sampled points (boreholes). Four main groups were distinguished G1, G2, G3 and G4.

-Group G1, borehole (FNia1) and presented high bacterial abundance;

-Group G2, boreholes (FBou and FNia2) presented high values of electrical conductivity and values bacterial $<1$ CFU/100mL;

-Group G3, borehole (FBat) had lower values of electrical conductivity and low bacterial abundance $(<1$ $\mathrm{CFU} / 100 \mathrm{~mL}$;

-Group G4 boreholes (FBin and FNdr) were characterized by very lower values of electrical conductivity and bacterial values $(<1 \mathrm{CFU} / 100 \mathrm{~mL})$. 


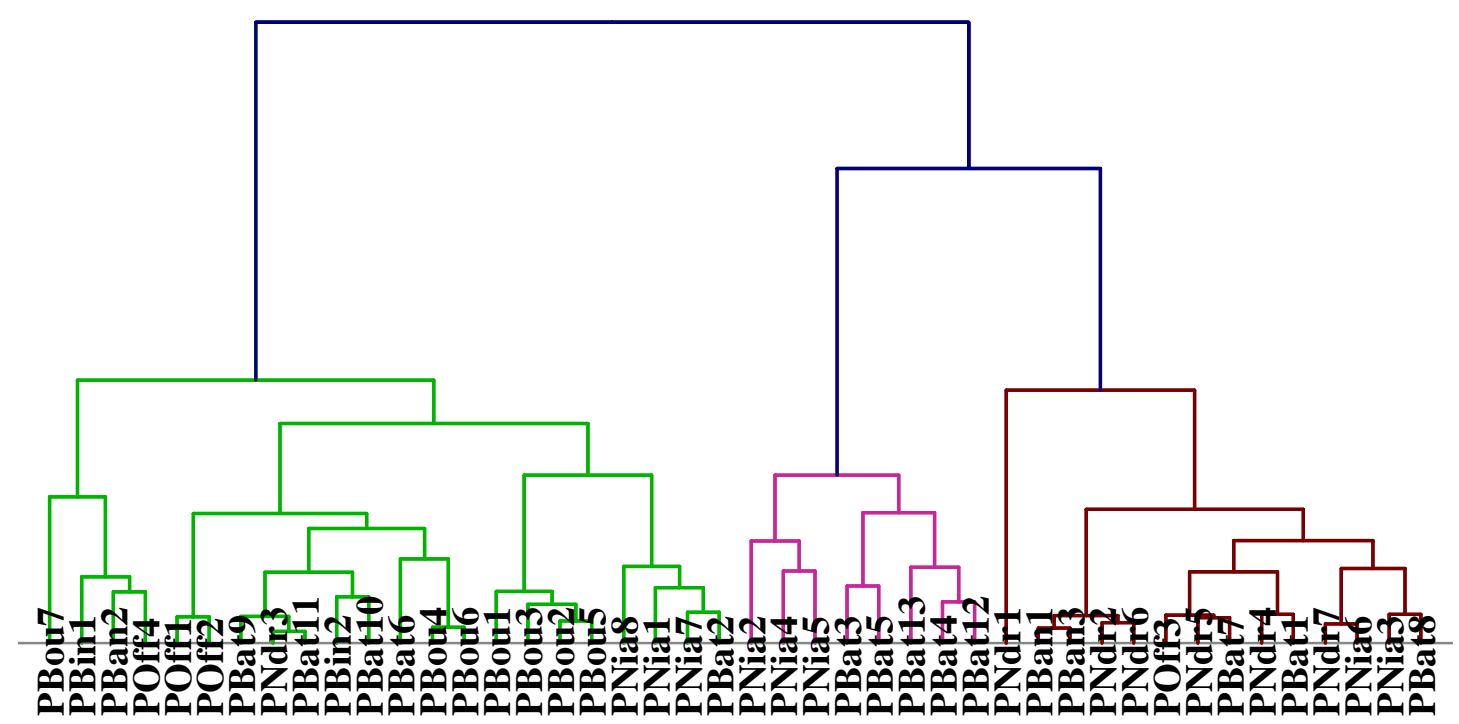

Fig. 12:-Dendrogram showing the hierarchical clusters of sampled hand dug wells.

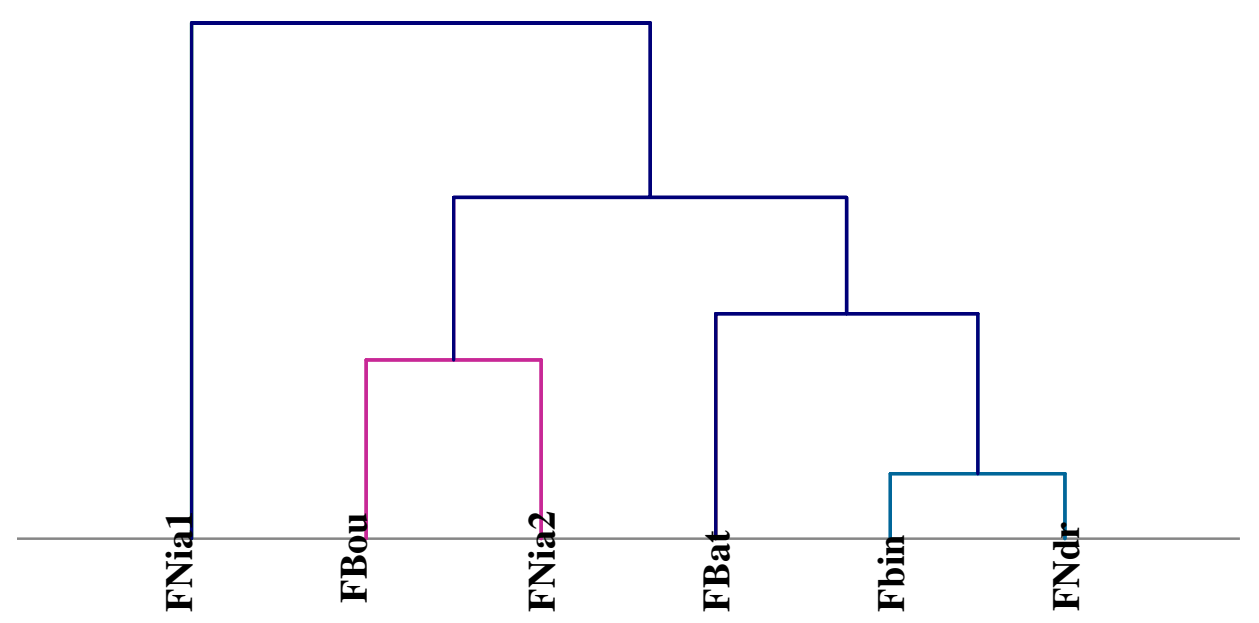

Fig. 13:-Dendrogram showing the hierarchical clusters of sampled boreholes.

\section{Discussion:-}

The population of the different localities surveyed mainly obtain water from hand dug wells and boreholes. Majorities of water sample from hand dug wells and boreholes were acid. The acidity or basicity of water is expressed as $\mathrm{pH}(<7.0$ acidic ; $>7.0$ basic). The normal $\mathrm{pH}$ range for domestic or drinking water is from 6.5 to 8.5 according to OMS (2004). This acidity of the waters is in agreement with that obtained by Ahoussi (2008) on the groundwater of the department of Agboville. It is consistent with the waters encountered in Côte d'Ivoire in basement aquifers. This aspect of groundwater has been reported in several studies including Soro (2014) in a watershed from Upper Bandama to Tortiya where well water had an average $\mathrm{pH}$ of 5,1. Low $\mathrm{pH}$ in groundwater is common in deep groundwater sources. It is caused by the presence of carbon dioxide, which is generated in the soil 
by both aerobic and anaerobic microbial processes coupled with the fact that at such depths it cannot easily escape into the atmosphere (Sawyer et al., 1994). Exposure to extreme pH values (less than 4 and greater than 11) may result in irritation of the eyes, skin and mucous membranes (WHO, 1996). The ranges of $\mathrm{pH}$ found in the study (4.47) may therefore be said not to be extreme and appear to fall in the range of common reported values from studies elsewhere.

In practice, the temperature of the water does not have a direct impact on human health. However, a high temperature (above $20^{\circ} \mathrm{C}$ ) promotes the growth and development of organisms living in water and especially microorganisms. The chemical and biochemical reactions, the density, the viscosity, the solubility of gases in water, the dissociation of dissolved salts depend on the temperature (Rodier et al., 2009). The temperatures above $25^{\circ} \mathrm{C}$ obtained in this study do not constitute a danger to the consumer. Orou et al. (2016) in their work on groundwater quality in Agboville have shown temperature values above $25^{\circ} \mathrm{C}$. These results are consistent with those of Reggam et al. (2015) in Algeria. Temperature affects the state and level of other parameters including conductivity.

Clarity of water is said to be a major factor in consumer satisfaction. Thus, turbidity has been used over many years as an indicator of drinking water quality and as an indicator of the efficiency of drinking water coagulation and filtration processes. He has been described as a relatively crude method of detecting a wide variety of particles from a wide assortment of sources as it provides no information about the nature of the particles. A total of $98 \%$ of the water from hand dug wells exceeded WHO Guideline value limit ( 5 NTU). The high turbidity may be as a result of the presence of colloidal and suspended matter (such as clay, silt, finely divided organic and inorganic matter, plankton, and other microscopic organisms). The added presence of turbidity increases the apparent, but not the true colour of water. Consumers do not generally accept turbid water and normally associate such water with possible wastewater pollution and the health risks that go with that especially in urban areas (Sawyer et al., 1994). The low values obtained for borehole water could be justified by the protection of the well against infiltration of surface loaded with suspended matter.

Nitrates and nitrites are regular chemical compounds in nature that commonly dissolve in water and migrate naturally to groundwater. Nitrate is one of the major anions in natural waters, but concentrations can be greatly elevated due to leaching of nitrogen from farm fertilizers. A total of $25 \%$ of waters from hand dug wells exceeded limit $(50 \mathrm{mg} / \mathrm{L})$ recommended by WHO for drinking water and $48 \%$ exceeded the nitrites limit $(0,1 \mathrm{mg} / \mathrm{L})$. These results are in agreement with those found by Yao et al. (2012) in the southwest of Côte d'Ivoire. The assessment of the chemical potability of groundwater indicated values above the limit by the WHO for nitrates and nitrites. These are waters unfit for human consumption. The harmful effects of nitrates are related to the transformation of nitrates into nitrites and possibly into nitrosamines in the digestive tract. In humans, nitrites are responsible for the risks of acute methaemoglobinaemia, which is mainly observed in infants and pregnant women. High levels of nitrite and nitrate can come from human activities demonstrating that the water resources of the region are not immune to pollution by pesticides that are heavily used in cocoa, coffee, rubber plantations. According to Heriarivony et al. (2016), the high levels of nitrites sometimes correspond to the reduction of nitrates to nitrites by aerobic reducing bacteria. The level of well protection contributes significantly to groundwater pollution.

Bacteria was found in most of the samples, indicated a deterioration of the well water quality. In many cases (93 $\%$ ), water from hand dug wells were contaminated by Escherichia Coli and $100 \%$ by feacal enterococci. These results corroborate those found by Akple et al. (2011) in Kumasi (Ghana). They recorded high contamination levels in the waters of dug wells studied. Hand dug wells in study area are the simplest well system. They are dug with little technicality. Protective equipment is practically non-existent, such as surface installations and the use of a pulley or pump for water collection. The principles of well construction are neglected. These are wells built at the request of the populations to meet the different water needs. In fact, good practice for well construction and operation is based on a few actions that are not always employed, like well positioning far from latrines and other sources of contamination, water withdrawal through pumps, waterproofing of headwall and wells surrounding area, construction of a fencing to avoid animal presence close to the well. Well water can also be contaminated through tools that are in contact with water.

In the study area, the main tool that is in contact with the water of the well is the bucket and the rope of the latter for the water collection. This traditional method of collecting water presents several risks of fecal contamination. Buckets are generally poorly maintained and placed on the floor. They may be in contact with nearby fecal deposits. Insects that land on the bucket can also be a source of contamination by bringing fecal pathogens through their paws 
or saliva. Poor sanitation and open defecation is another cause and threat of drinking water contamination in the area. In our study, a large number of the samples tested showed the presence of saprophytes, including Pseudomonas aeruginosa. The detection of Pseudomonas aeruginosa has been advocated as a method of assessing the hygienic quality of drinking water. Microbial contamination of water persists because of the incorrect construction of wells or the inappropriate behaviour of well users.

This situation is typical in many rural areas in the greater part of developing countries, where water caught from domestic wells is often characterized by organic and microbiological contamination. These wells could pose a critical factor in the transmission of water-borne pathogens between the human populations. Drinking of contaminated well water can contribute to high morbidity and mortality rates from diarrhoeal diseases and sometimes lead to epidemics (Abu-Amr and Yassin, 2008). The microbiological contamination of water is a global problem. It is estimated that unsafe water and a lack of basic sanitation led to at least 1.6 million deaths in children under the age of 5 years in 2004, and 1.8 million deaths, including adults, occur from diarrhoeal diseases every year (WHO, 2006).

The microbiological quality of $83 \%$ of water from the boreholes was acceptable for human consumption. $17 \%$ of the boreholes waters was contaminated with indicator bacteria. This is probably due to the depth at which water from boreholes was sampled. The minimum borehole depth sampled was $44 \mathrm{~m}$. Borehole water is generally of excellent quality because rocks act as filters. Microbial contamination from surface sources is removed within the first $30 \mathrm{~m}$ as groundwater passes through saturated sand or unfissured rock. In the unsaturated zone no more than 3 $\mathrm{m}$ may be necessary to purify ground water. However, in a fractured aquifer microbial contaminants can rapidly pass through the unsaturated zone to the water table. The efficiency of the purifying process is reduced under these circumstances.

There is a need to educate the public about the quality of their water sources and the importance of clean and healthy surroundings near water sources and to implement measures to prevent the contamination of water sources in the community. Boiling water is advised until disinfection and retesting to confirm that the contamination has been eliminated. In fact, numerous recent studies have shown that household water treatment and safe storage is crucial to reduce diarrhoeal and other enteric diseases (Nath, 2003).

\section{Conclusion:-}

It is concluded from the current study that, drinking water of the study area at source, are predominantly contaminated with nitrates, nitrites and bacteria indicators. It is risk of waterborne infection. Protection of the drinking water sources is necessary to prevent the spread of waterborne infection and improve water quality. Monitoring of microbial water quality with catchment analysis and risk assessment is needed regularly in order to trace out the possible means of contamination and its improvement. Reduction and proper management of animal and human waste can reduce the risk of water contamination in the area. Good health and hygiene practice with community awareness regarding the use of latrine and related waste management facilities is needed to get proper attention. Extension of hygiene education and sanitation found to have vital importance on the provision of safe water supply. Use of disinfectant and boiling of the drinking water can reduce the risk of pathogens intake.

\section{References:-}

1. Abu-Amr, S. S. and Yassin, M. M. (2008). Microbial contamination of the drinking water distribution system and its impact on human health in Khan Yunis Governorate, Gaza Strip: Seven years of monitoring (20002006). Public Health, 122 : 1275-1283.

2. Ahoussi, K. E. (2008). Evaluation quantitative et qualitative des ressources en eau dans le Sud de la Côte d'Ivoire. Application de l'hydrochimie et des isotopes de l'environnement à l'étude des aquifères continus et discontinus de la région d'Abidjan-Agboville. Thèse de Doctorat Unique, Université de Cocody Abidjan, Côte d'Ivoire, $270 \mathrm{p}$.

3. Akbar, A. and Anal, K. A. (2011). Food safety concerns and food-borne pathogens, Salmonella, Escherichia coli and Campylobacter. J. Biol., 1 (1) : 5-17.

4. Akple, M., Keraita, B., Konradsen, F. and Agbenowu, E. (2011). Microbiological quality of water from handdug wells used for domestic purposes in urban communities in Kumasi, Ghana. Urban Water J., 8 (1) : 57-64. 
5. APHA, (American Public Health Association). (2012). Standard Methods for the Examination of Water and Wastewater $\left(22^{\text {nd }}\right.$ edn). American Public Health Association/American Water Works Association/Water Environment Federation: Washington, DC, USA.

6. Davraz, A. and Varol, S. (2011). Microbiological risk assessment and sanitary inspection of Tefenni (Burdur/Turkey) region. Environ. Earth Sci, 66 : 1213-1223.

7. Ferretti, E., Bonadonna, L., Lucentini, L., Libera, S.D., Semproni, M. and Ottaviani, M. (2010). A case study of sanitary survey on community drinking water supplies after a severe (post-Tsunami) flooding event. Annali dell'Istituto Superiore di Sanità, 46 (3) : 236-241.

8. Godfrey, S., Timo, F. and Smith, M. (2006). Microbiological risk assessment and management of shallow groundwater sources in Lichinga, Mozambique. Water Environ J., 20 : 194-202.

9. Heriarivony, S. C., Razanamparany, B. and Rakotomalala, J. E. (2016). Variations spatio-temporelles des paramètres physico-chimiques des eaux souterraines de la commune rurale d'Antanifotsy, Vakinankaratra, Madagascar. Larhyss Journal, 27: 239-255.

10. Huttly, S.R. (1990). The impact of inadequate sanitary condition on health in developing countries. World Health Stat. Q., 43 : 118-126.

11. INS, (2014). Recensement Général de la Population et de l'Habitat. Résultats globaux par sous-préfecture. (Côte d'Ivoire), $10 \mathrm{p}$.

12. Joyce, T. M., Meguigan, K. G., Elmore-Meegan, M. and Conroy, R. M. (1996). Inactivation of fecal bacteria in drinking water by solar heating. J. Appl. Environ. Microbiol., 62 (2) : 399-402.

13. Lima, J. R. O., Marques, S. G., Gonçalves, A. G., Filho, N. S., Nunes, P. C., Silva, H. S., Monteiro, S. G. and Costa, J. M. L. (2005). Microbiological analyses of water from hemodialysis services in são luís, maranhão. Brazil. Braz. J. Microbiol., 36 : 103-108.

14. Muhammad, N., Bangush, M. and Khan, A. T. (2012). Microbial contamination in well water of temporary arranged camps: A health risk in northern Pakistan. Water Quality Exposure and Health, 4 (4) : 209-215.

15. Muhammad, F., Ikram, M., Khan, S., Khan, K., Shah, S. H., Badshah, Z., Ahmad, W. and Shah, S. N. (2013). Flood disaster in Charasadda, Pakistan: Bacteriological examination of drinking water. Int. J. Biosci., 3 (5) : 51 59.

16. Mushi, D., Byamukama, D., Kirschner, A., Mach, R. and Farnleitner, A. (2012). Sanitary inspection of wells using risk-of-contamination scoring indicates a high predictive ability for bacterial faecal pollution in the periurban tropical lowlands of Dar es Salaam, Tanzania. J. Wat. Health, 10 (2) : 236-243.

17. Nath, K. (2003). Home hygiene and environmental sanitation: A country situation analysis for India. Int. J. Environ. Res. Public Health, 13: 19-28.

18. Nickson, R.T., McArthur, J.M., Shrestha, B., Kyaw-Myint, T.O. and Lowry, D. (2005). Arsenic and other drinking water quality issues, Muzaffargarh district, Pakistan. Appl. Geochem., 20 : 55-68.

19. OMS (2004). Directives de qualité pour l'eau de boissons, 3eme édition, volume 1 recommandations, Genève, $110 \mathrm{p}$.

20. Orou, R. K., Soro, G., Soro, D. T., Fossou, R., Onetie, O. Z. and Ahoussi, E. K. (2016). Variation Saisonnière De La Qualité Physico-Chimique Des Eaux Souterraines Des Aquifères d'Altérites Du Département d'Agboville (Sud-Est De La Côte d'Ivoire). Eur. Sci. J., 12 (17) : 1857 - 7881.

21. Reggam, A., Bouchelaghem, H. and Houhamdi, M. (2015). Qualité physico-chimique des eaux de l'Oued Seybouse (Nord-Est de l'Algérie): caractérisation et analyse en composantes principales. J. Mater. Environ. Sci., 6 (5) : 1417-1425.

22. Rodier, J., Legube, B. and Merlet, N. (2009). L'analyse de l'eau, $9^{\text {ème } e ́ d i t i o n, ~ E d . ~ D u n o d, ~ 1579 p . ~}$

23. Sawyer, C., McCarty, P. and Parkin, G. (1994). Chemistry for Environmental Engineering, fourth ed. McGrawHill, New York. 90 p.

24. Shar, A. H., Kazi, Y. F., Kanhar, N. A., Soomro, I. H., Zia, S. M. and Ghumro, P. B. (2010). Drinking water quality in Rohri City, Sindh, Pakistan. Afr. J. Biotechnol, 9 (42) : 7102-7107.

25. Soro, T. D. (2014). Evolution des ressources en eau du bassin versant du Haut Bandama à Tortiya (Nord de la Côte d'Ivoire) dans un contexte de variabilité et de changement climatiques : impacts hydrologiques, hydrogéologiques et hydrochimiques. Thèse de Doctorat Unique, Université Félix Houphouët-Boigny, Côte d'Ivoire, $243 \mathrm{p}$.

26. Standard Methods for the Examination of Water and Wastewater (1995). 19th edition, American Public Health Association/ American Water Works Association/ Water Environment Federation, Washington, DC.

27. Vaccari, M., Collivignarelli, C., Tharnpoophasiam, P. and Vitali F. (2010). Well sanitary inspection and water quality monitoring in Ban Nam Khem (Thailand) 30 months after 2004 Indian Ocean Tsunami. Environ. Monit. Assess, 161: 123-133. 
28. WHO. (World Health Organization) (1996). Guidelines for Drinking-Water Quality. Health Criteria and Other Supporting Information. Second edition, volume 2. Geneva, Switzerland.

29. WHO. (1997). Guidelines for Drinking Water Quality. Surveillance and Control of Community Supplies. Second edition, volume 3. Geneva, Switzerland.

30. WHO. (2000). Global water supply and sanitation assessment (report), New York/Geneva. 80p.

31. WHO. (2004). Water, sanitation and hygiene links to health, facts and figures. Geneva.

32. WHO. (2006). Meeting the Millennium Development Goals Drinking Water and Sanitation Target: The Urban and Rural Challenge of the Decade. WHO, Geneva, Switzerland.

33. Yao, T. K., Oga, M., Fouché, O., Baka, D., Pernelle, C. and Biemi, J. (2012). Évaluation de la potabilité chimique des eaux souterraines dans un bassin versant tropical : cas du Sud-Ouest de la Côte d'Ivoire. Int. J. Biol. Chem. Sci., 6 (6) : 7069-7086. 